\title{
Estimation of the period of permanence of Cordia americana seedlings in protected environment
}

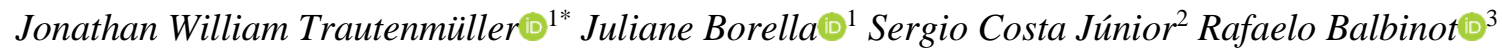 \\ Renata Reis de Carvalho ${ }^{2}$ Antonio Pedro Fragoso Woycikievicz ${ }^{2}$
}

\begin{abstract}
${ }^{1}$ Universidade Federal do Paraná, Rua dos Funcionários, 1540, Cabral, Campus Agrárias, CEP 80035-050, Curitiba, PR, Brasil. ${ }^{2}$ Universidade Federal do Paraná, Av. Pref. Lothário Meissner, 632, Jardim Botânico, Campus III, CEP 80210-170, Curitiba, PR, Brasil. ${ }^{3}$ Universidade Federal de Santa Maria, Rua Sete de Setembro, s/n, 98400-000, Campus Frederico Westphalen, Frederico Westphalen, RS, Brasil.
\end{abstract}

\section{Original Article \\ *Corresponding author: jwtraute@gmail.com}

Keywords:

Production of seedlings

Morphologic parameters

Quality of the seedlings

Palavras-chave:

Produção de mudas

Parâmetros morfológicos

Qualidade das mudas

Received in

2019/06/01

Accepted on

2019/12/19

Published in

2020/04/03

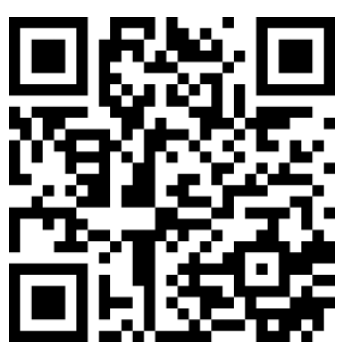

DOI:http://dx.doi.org/10.340 62/afs.v7i1.8459

\section{(cc) BY}

\begin{abstract}
The use of new tools as the technical criterion of interception of the curves of average daily increment and current daily are useful for indicating the optimal period of permanence of the plants in the protected environment. The objective of this study was to determine the length of stay of the Cordia americana (Linnaeus) Gottshling \& JE Mill seedlings in protected environment based on the morphological parameter's height, base diameter and total dry mass of the seedlings and in the intercept between daily increment curves and increment daily average. The experiment was conducted in a randomized complete block design with four treatments and five replications. The criteria were defined based on the growth curves and intercept between curves of daily increment and average daily increment. The volume of substrate that could be explored by the root system and the density of seedlings per tray influenced the growth, in general larger seedlings were obtained in larger tubes. The period of stay of the seedlings in the nursery varies from 150 to 250 days depending on the treatment used using the dry mass as a quality parameter. The technical criterion used to intercept the curves of daily increment and average daily increment is useful in decision making, with a view to the evaluation of the quality standard of the seedlings.
\end{abstract}

\section{Estimativa do período de permanência de mudas de Cordia americana em ambiente protegido}

RESUMO: O emprego de novas ferramentas como o critério técnico de interceptação das curvas de incremento médio diário e corrente diário é útil para indicação do período ótimo de permanência das plantas no ambiente protegido. $\mathrm{O}$ objetivo foi determinar o período de permanência das mudas de Cordia americana (Linnaeus) Gottshling \& J.E. Mill em ambiente protegido baseado nos parâmetros morfológicos altura, diâmetro do colo e massa seca total das mudas e no intercepto entre as curvas de incremento corrente diário e incremento médio diário. $\mathrm{O}$ experimento foi conduzido em delineamento experimental de blocos completos casualizados, contendo quatro tratamentos e cinco repetições. Os critérios foram definidos com base nas curvas de crescimento e intercepto entre curvas de incremento corrente diário e incremento médio diário. $\mathrm{O}$ volume de substrato explorável pelo sistema radicular e a densidade de mudas por bandeja influenciaram no crescimento, em geral mudas com maiores dimensões foram obtidas nos recipientes maiores. O período de permanência das mudas no viveiro varia de 150 a 250 dias dependendo do tratamento utilizado usando a massa seca como parâmetro de qualidade. O critério técnico utilizado de intercepto entre as curvas de incremento corrente diário e incremento médio diário é útil na tomada de decisão, com vistas à avaliação do padrão de qualidade das mudas. 


\section{Introduction}

The implantation of forest essences for the recovery of degraded areas and areas of permanent preservation, especially the genus Cordia, can be carried out with seedlings produced in a protected environment. The quality of the seedlings is important to increase the survival of the plants in the field, as well as to accelerate the recompositing time (Abreu et al. 2015). Thus, the production of nursery seedlings is one of the most important stages in the process of reforestation implantation (Eloy et al. 2014). Some factors influence seedling quality, such as seed quality, type of container, substrate, management and time spent in the greenhouse. There are few studies that address the seedling residence time in the greenhouse, these studies are with exotic species (Mafia et al. 2005; Reis et al. 2008; Eloy et al. 2014), but with the genus Cordia there are no studies dealing with the seedling residence time in the greenhouse.

The volume of the tubes and the spacing between the plants in the protected environment are one of the factors that influence the growth, but when it involves native species, there is a great lack in studies. In general, higher seedling density favors selection of the most vigorous plants, removing low quality individuals (Eloy et al. 2014). Thus, the best arrangement between the seedlings provides uniformity in growth, more homogeneous and allowing greater control over the period of permanence of the individuals in the protected environment (Reis et al. 2008).

The use of new tools as the technical criterion of interception of the curves of average daily increment and current daily, are useful for indicating the optimal period of permanence of the plants in the protected environment (Mafia et al. 2005). However, this methodology can be considered as a new technique to evaluate the quality of the seedlings that directly reflects the performance and survival in the field (Mafia et al. 2005). This procedure was used only to determine the optimal period of permanence of Eucalyptus seedlings in the work of Mafia et al. (2005) and Eloy et al. (2014), demonstrating the necessity of these studies with native species. The use of tubes with inappropriate shapes and volumes is directly related to the deformities presented by the root system of plants produced in nurseries. These receptors provide abnormal growth in the distribution of the superficial and lateral roots, causing the imbalance in the absorption of nutrients and water in quantities essential for the molt (Alfenas et al. 2004). This is due to the imbalance between root dry mass and dry shoot mass (Mafia et al. 2005).

Thus, the present study had the objective of determining the length of stay of Cordia americana (Linnaeus) Gottshling \& JE Mill in a protected environment based on the morphological parameter's height, base diameter and total dry mass of the seedlings and the intercept between the curves daily increment and average daily increment.

\section{Materials and Methods}

The study was carried out with the Cordia americana (Linnaeus) Gottshling \& JE Mill from September 2014 to February 2015, in a protected environment with Pampeana type greenhouse, with a low-density polyethylene cover, $150 \mathrm{~mm}$ thickness. The experiment was conducted in the forest nursery of the Federal University of Santa Maria, Campus of Frederico Westphalen, under geographic coordinates $27^{\circ} 23^{\prime} 46^{\prime \prime} \mathrm{S}$ and $53^{\circ} 25^{\prime} 38^{\prime \prime}$ $\mathrm{W}$ at $480 \mathrm{~m}$ altitude.

The climate of the region according to the classification of Köppen is Humid Subtropical (Cfb) (Alvares et al. 2013), with rainfall regime balanced, however, to the reduction of precipitation in the winter season, annual average between 1,700 and $1,900 \mathrm{~mm}$ and average temperature between 20 and $23^{\circ} \mathrm{C}$ (Rossato, 2014).

The production of the seedlings was made from seeds from the company MP® seeds. At the sowing, performed on September 26, 2014, 4 seeds were placed per tube filled with commercial substrate (Tecnomax $®)$. All treatments received base fertilization with five $\mathrm{kg}$ of slow release fertilizer with formula $15-09-12$ per $\mathrm{m}^{3}$ of substrate. At 40 days after sowing, a thinning of the seedlings was done, leaving only the best and most central.

The experiment was conducted in a randomized block design with four treatments and five replications. Each block consisted of the following treatments: i) $170 \mathrm{~cm}^{3}$ tube with $100 \%$ (T1) and; ii) $50 \%$ (T2) occupancy; iii) $90 \mathrm{~cm}^{3}$ tube with $100 \%$ (T3) and; iv) $50 \%$ (T4) in the tray. Each experimental unit consisted of 35 and 28 plants, respectively, for $100 \%$ (high density) and 50\% (average density) tray occupancy, with the 10 central plants being evaluated and the others as the border composing, when two seedlings per treatment and repetition were sampled. From the 60 days after sowing, five evaluations were performed, with intervals of 20 days. The high density corresponded to 434 and 237 plants per $\mathrm{m}^{2}$ and the average density of 217 and 118 plants per $\mathrm{m}^{2}$, for large and medium tube, respectively. During the experiment, daily watering was carried out in an automated way, reaching the field capacity of the substrate.

The following morphological characteristics were evaluated: shoot height $(\mathrm{H})$, base diameter (BD) and total dry mass (TDM). The $\mathrm{H}$ was determined from the substrate level up to the tip of the last sheet, using a ruler graduated in millimeters, and the BD was measured at the substrate level with the aid of a digital caliper, with millimeter precision.

The determination of the TDM was made from the weighing of the plant, with subsequent drying of the materials in a greenhouse with forced ventilation at 
$65^{\circ} \mathrm{C}$ until constant weight, being weighed with the help of an electronic scale, with precision of four decimal places.

For each parameter evaluated, we adjusted the logistic model proposed by Leite and Oliveira (2002), defined by:

$$
Y=\alpha\left(1+\beta e^{-\gamma T}\right)+\varepsilon
$$

In which: $Y=$ evaluated variable; $T=$ period in days; $\alpha, \beta$ and $\gamma=$ coefficients of the model; $\varepsilon=$ error.

From this model, it is possible to calculate the daily increment and daily average increment defined by Leite and Oliveira (2002) and calculated by the derivative $\frac{d Y}{d T}=\gamma^{Y}(\alpha-Y) / \alpha$ and used in determining the technical rotation, in that $Y, T, \alpha$ and $\gamma$ retain the meaning quoted above.

The coefficients of the logistic model (Table 1) were estimated by regression using the $5 \%$ level of significance, using SAS Learning Edition 8.0 software (2003).

Table 1: Morphological parameters, treatments and coefficients of the logistic model $(\alpha, \beta$ and $\gamma)$ and determination $\left(\mathrm{R}^{2}\right.$ aj) used to define the relationship between height, base diameter and total dry mass of the American Cordia seedlings (Ys) in function of age $(\mathrm{T})$.

\begin{tabular}{|c|c|c|c|c|c|}
\hline \multirow{3}{*}{$\begin{array}{c}\text { Morphological } \\
\text { Parameters }\end{array}$} & \multirow{3}{*}{ Treatments } & \multicolumn{3}{|c|}{ Equation Coefficients } & \multirow{3}{*}{$R^{2}$ aj } \\
\hline & & \multicolumn{3}{|c|}{$Y=\alpha\left(1+\beta e^{-\gamma T}\right)^{-1}+\varepsilon$} & \\
\hline & & $\alpha$ & $\mathrm{B}$ & $\gamma$ & \\
\hline \multirow{4}{*}{ Height (cm) } & $\mathrm{T} 1$ & 20.0267 & 81.6547 & 0.0560 & 0.98 \\
\hline & $\mathrm{T} 2$ & 15.8413 & 73.7700 & 0.0562 & 0.99 \\
\hline & $\mathrm{T} 3$ & 17.1552 & 53.0926 & 0.0484 & 0.99 \\
\hline & $\mathrm{T} 4$ & 14.1007 & 29.3713 & 0.0431 & 0.98 \\
\hline \multirow{4}{*}{ Base diameter (mm) } & $\mathrm{T} 1$ & 5.6029 & 14.2145 & 0.0381 & 0.99 \\
\hline & $\mathrm{T} 2$ & 5.6213 & 25.6681 & 0.0454 & 0.99 \\
\hline & $\mathrm{T} 3$ & 5.3346 & 20.7570 & 0.0354 & 0.98 \\
\hline & $\mathrm{T} 4$ & 5.5283 & 10,8425 & 0,0270 & 0,98 \\
\hline \multirow{4}{*}{ Total dry mass (g) } & $\mathrm{T} 1$ & 3.3955 & 291.8 & 0.0513 & 0.94 \\
\hline & $\mathrm{T} 2$ & 3.0965 & 198.3 & 0.0475 & 0.95 \\
\hline & $\mathrm{T} 3$ & 7.5032 & 135.2 & 0.0261 & 0.94 \\
\hline & $\mathrm{T} 4$ & 2.8378 & 79.4 & 0.0345 & 0.92 \\
\hline
\end{tabular}

Where: $\mathrm{T} 1$ = large tube + high density; $\mathrm{T} 2$ = large tube + medium density; $\mathrm{T} 3$ = medium tube + high density and $\mathrm{T} 4=$ medium tube + medium density.

\section{Results and discussion}

The height of the seedlings was influenced by the volume of the tubes $(\mathrm{P}<0.05)$ and the arrangement of the plants in the trays, based on the regression analysis. Considering the growth curves of all treatments (Figure 1A), these differ from the 60 days after emergence. At 140 days, T1 $\left(170 \mathrm{~cm}^{3}\right.$ tube with $100 \%$ occupancy) treatment seedlings presented higher mean height compared to the other treatments (Figure 1A). T1 is the combination of the largest volume of substrate available for exploration and less useful space between the seedlings. The smaller living space between the seedlings provides greater competition for solar radiation, favoring vertical growth (Eloy et al. 2014).

The density of the seedlings had no significant effect on the base diameter (Figure 1B), which was influenced only by the volume of available substrate. The growth curve for the base diameter shows the two points of inflection, but not finding the asymptote, the theoretical diameter of the asymptote can be considered as the $\alpha$ of the adjusted model. The total dry mass (Figure 1C) presented a significant difference for the different treatments but was more affected by the volume of the tube. The total dry mass is indicative of the amount of nutrients absorbed by the seedlings and, ultimately, their vigor (Eloy et al. 2014). 

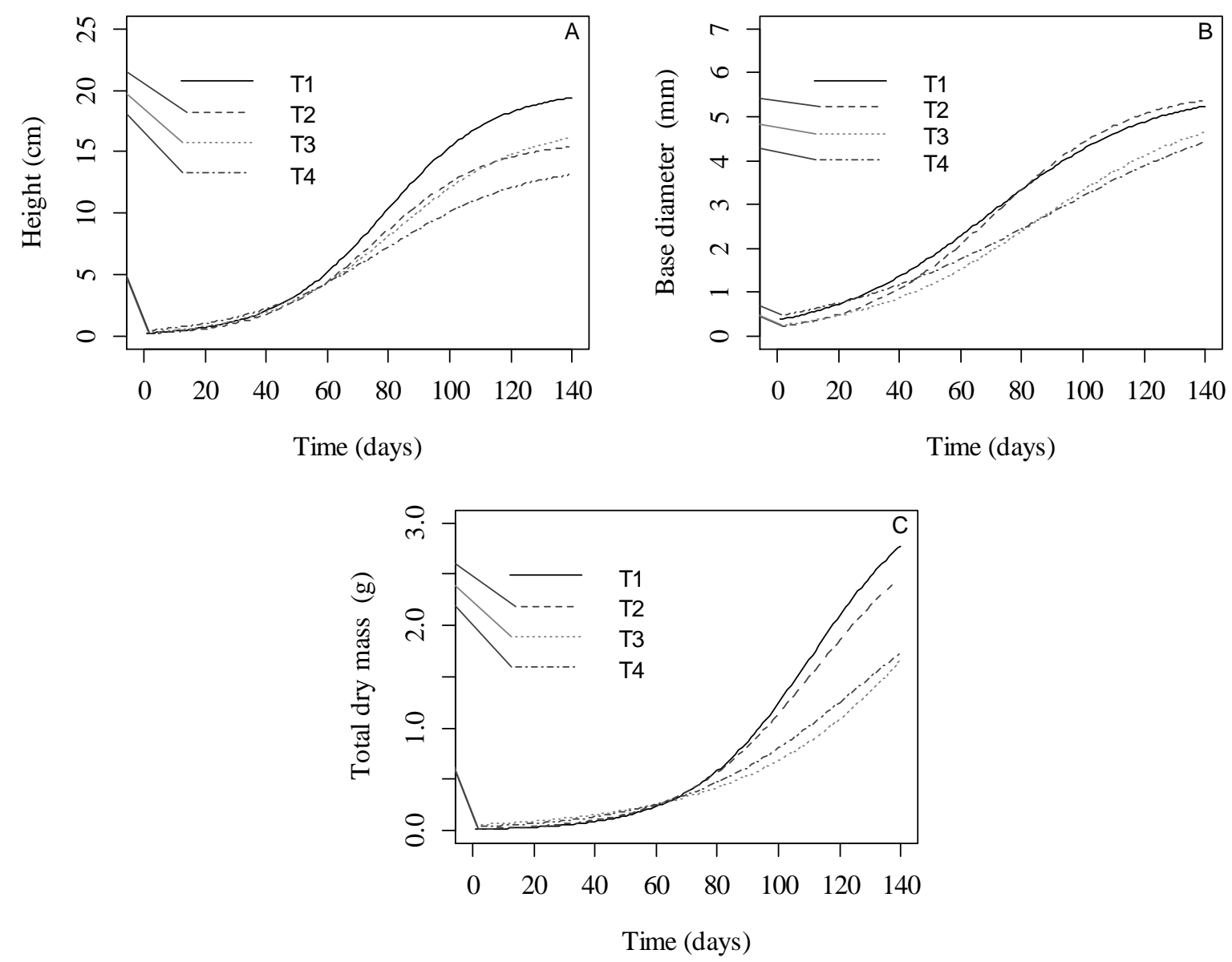

Figure 1: Mean height (A), mean base diameter (B) and mean total dry mass (C) as a function of the age of the American Cordia seedlings of the four treatments tested. In what: $\mathrm{T} 1=170 \mathrm{~cm}^{3}$ tube + high density; $\mathrm{T} 2=170 \mathrm{~cm}^{3}$ tube + medium density; T3 $=90 \mathrm{~cm}^{3}$ tube + high density and $\mathrm{T} 4=90 \mathrm{~cm}^{3}$ tube + medium density.

In order to recommend the shelf life of the plants in a protected environment, it was considered as technical criterion the intercept between daily increment curve and average daily increment curve for the variables evaluated (Eloy et al. 2014). Based on plant height as seedlings should be transplanted to the field 107 days after plant emergence for treatment T1, and 104, 113 and 108 days for treatments T2, T3 and T4, respectively (Figure 2).

In a similar study, Mafia et al. (2005) studying eucalyptus clones (Eucalyptus grandis W. Hill ex Maiden x Eucalyptus urophylla Blake), found periods of 82 and 110 days after plant emergence, to produce plants of good quality. The shortest period is related to the species studied, because the genus Eucalyptus grow faster when compared to the genus Cordia. On the other hand, Eloy et al. (2014) working with Eucalyptus grandis found periods of 138 to 163 days after emergence, for expedition of seedlings with good quality. These higher values found by Eloy et al. (2014) may be associated with the volume of substrate explored (50 and $90 \mathrm{~cm}^{3}$ ) and the non-application of the base fertilization, the authors also do not mention other applications. For the present work, $5 \mathrm{~kg}$ of slow release fertilizer was applied to each $\mathrm{m}^{3}$ of substrate.

The point at which the curves of daily increment and average daily increment intercept are defined as the optimal age for the expedition of the protected environment seedlings (Campos and Leite, 2006). When only the highest efficiency of plant growth, related to the average daily increment, is considered, the technical rotation of the crop is defined. However, it does not correspond to economic rotation, which uses other factors, such as production costs and current interest rates (Campos and Leite, 2006). Thus, the period of the intercept of the increment curves represents the maximum efficiency of the individual's growth, after that period the quality standard of the seedlings is impaired because the seedlings tend to stabilize the growth (Mafia et al. 2005). 

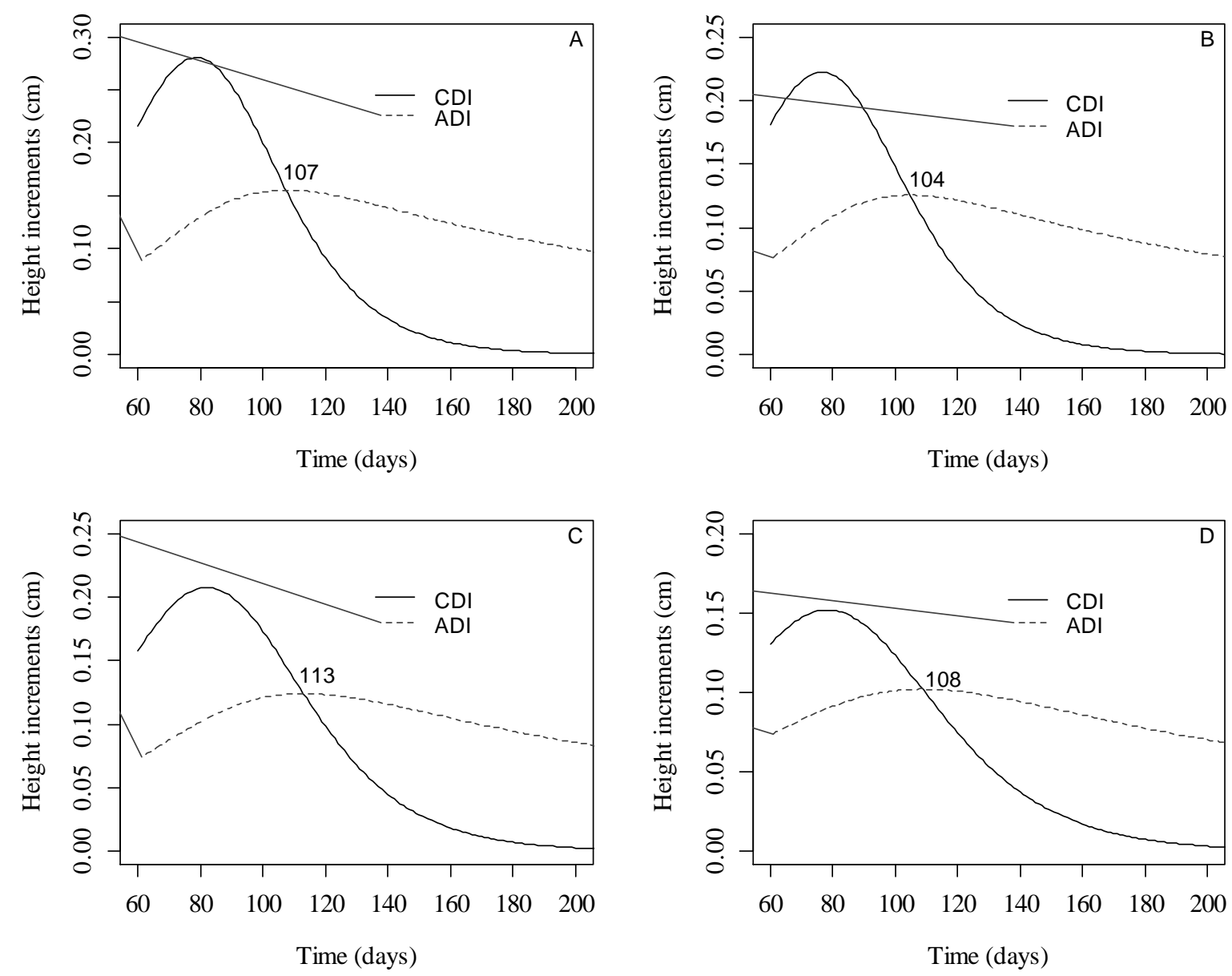

Figure 2: Current daily increments (CDI) and average daily increments (ADI) for height according to the age of the Cordia americana seedlings, according to the treatments: $\mathrm{T} 1=$ seedlings developing in large tubes $(170 \mathrm{~cm} 3)$ arranged in density high (237 tubes $\mathrm{m}-2)(\mathrm{A}) ; \mathrm{T} 2=$ in large tubes and medium density (118 tubes m-2) (B); T3 = medium tube $(90 \mathrm{~cm} 3)$ and high density $(434$ tubes $\mathrm{m}-2)(\mathrm{C})$ and $\mathrm{T} 4=$ medium tube + medium density $(217$ tubes $\mathrm{m}-2)(\mathrm{D})$.

Thereby, base diameter in the treatment $\mathrm{T} 1$ was found the age of 95 days after the emergence of the plants as the most suitable for the expedition of the seedlings of the nursery. For the T2, T3 and T4 treatments the defined age was 99, 119 and 116 days, respectively (Figure 3), showing that the larger tubes anticipate the moment of the expedition of the seedlings in 15 to 20 days when compared to the time of dispatch of seedlings produced in medium tubes, adopting the base diameter as reference.

The results demonstrated, when compared with the literature, show a certain similarity. Reis et al. (2008) determining the length of stay of Eucalyptus grandis seedlings, found values between 100 and 115 days, after the emergence of the plants, as the best indicated for the expedition with a good quality standard. However, the length of stay of the seedlings in the nursery may be longer, considering the height and diameter of the seedling base of Tabebuia impetiginosa, Cunha (2005), found a period of 180 days of stay in the nursery, a difference caused by difference between the characteristics of each species.

Considering the total dry mass, in the T1 treatment, the age of 148 days after the emergence of the plants as the most suitable for the expedition of the nursery seedlings was observed, and for T2, T3 and T4 treatments the defined age was 149, 254 and 173 days, respectively (Figure 4).

For Alfenas et al. (2004), seedlings that have a higher standard of quality, present better conditions of growth and competition in the field. These characteristics can be affected by the time of permanence in the nursery, since from the moment the ideal period of rotation in the nursery is exceeded. The root system of the seedlings tends to present folding, imposed by the restriction of the explorable substrate space, in addition to suffer reduction of leaf area and present fragility to certain diseases. Is more suitable variable to evaluate the seedlings permanence time should be used for seedling dry mass. 

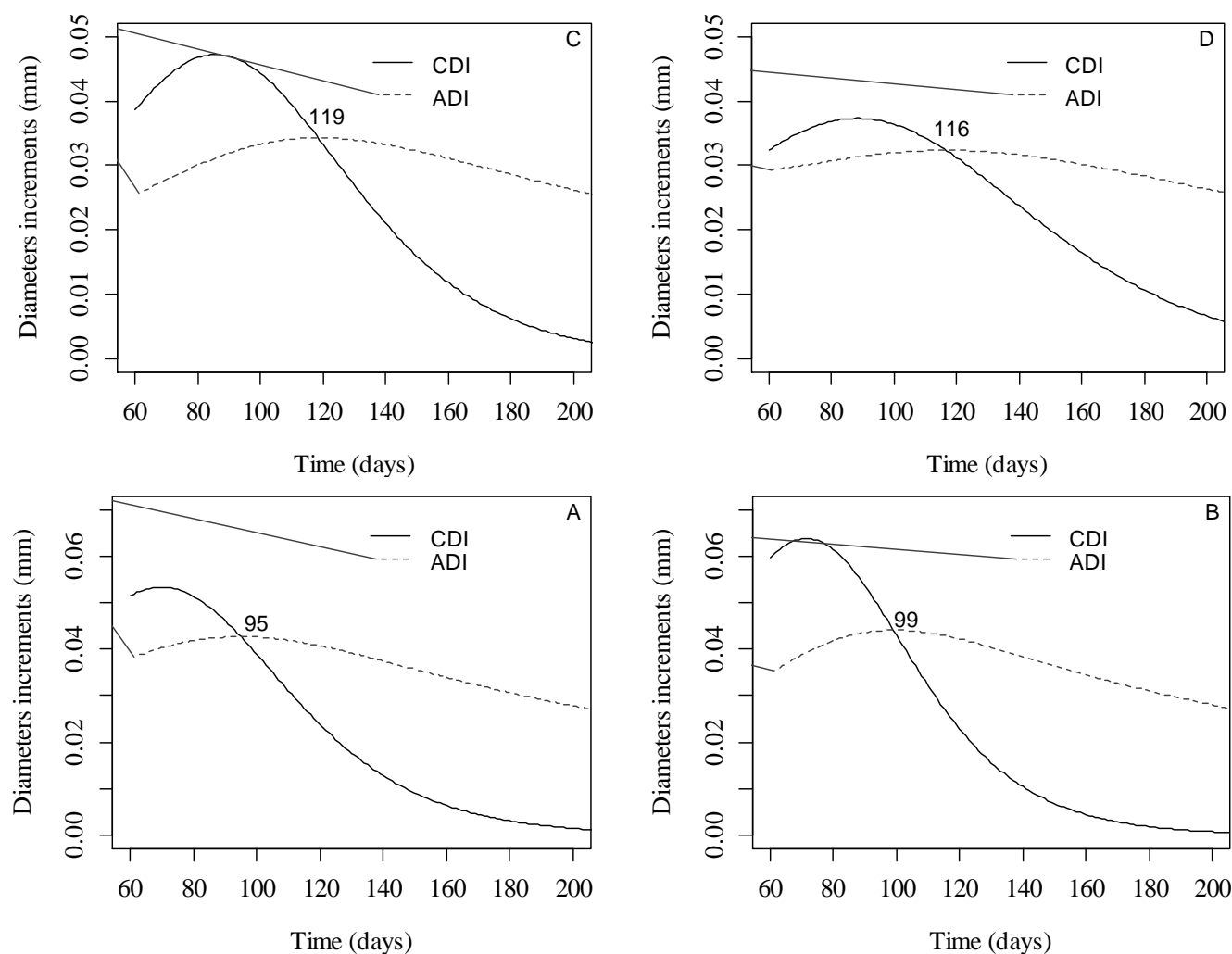

Figure 3: Current daily increments (CDI) and average daily increments (ADI) for the base diameter according to the age of the Cordia americana seedlings, according to the treatments: $\mathrm{T} 1=$ seedlings developing in large (170 $\left.\mathrm{cm}^{3}\right)$ in high density $\left(237\right.$ tubes $\left.\mathrm{m}^{-2}\right)(\mathrm{A}) ; \mathrm{T} 2=$ in large tubes and medium density $\left(118\right.$ tubes $\left.\mathrm{m}^{-2}\right)(\mathrm{B}) ; \mathrm{T} 3=$ medium tube $\left(90 \mathrm{~cm}^{3}\right)$ and high density $\left(434\right.$ tubes $\left.\mathrm{m}^{-2}\right)(\mathrm{C})$ and $\mathrm{T} 4=$ medium tube + medium density $\left(217\right.$ tubes $\left.\mathrm{m}^{-2}\right)(\mathrm{D})$.
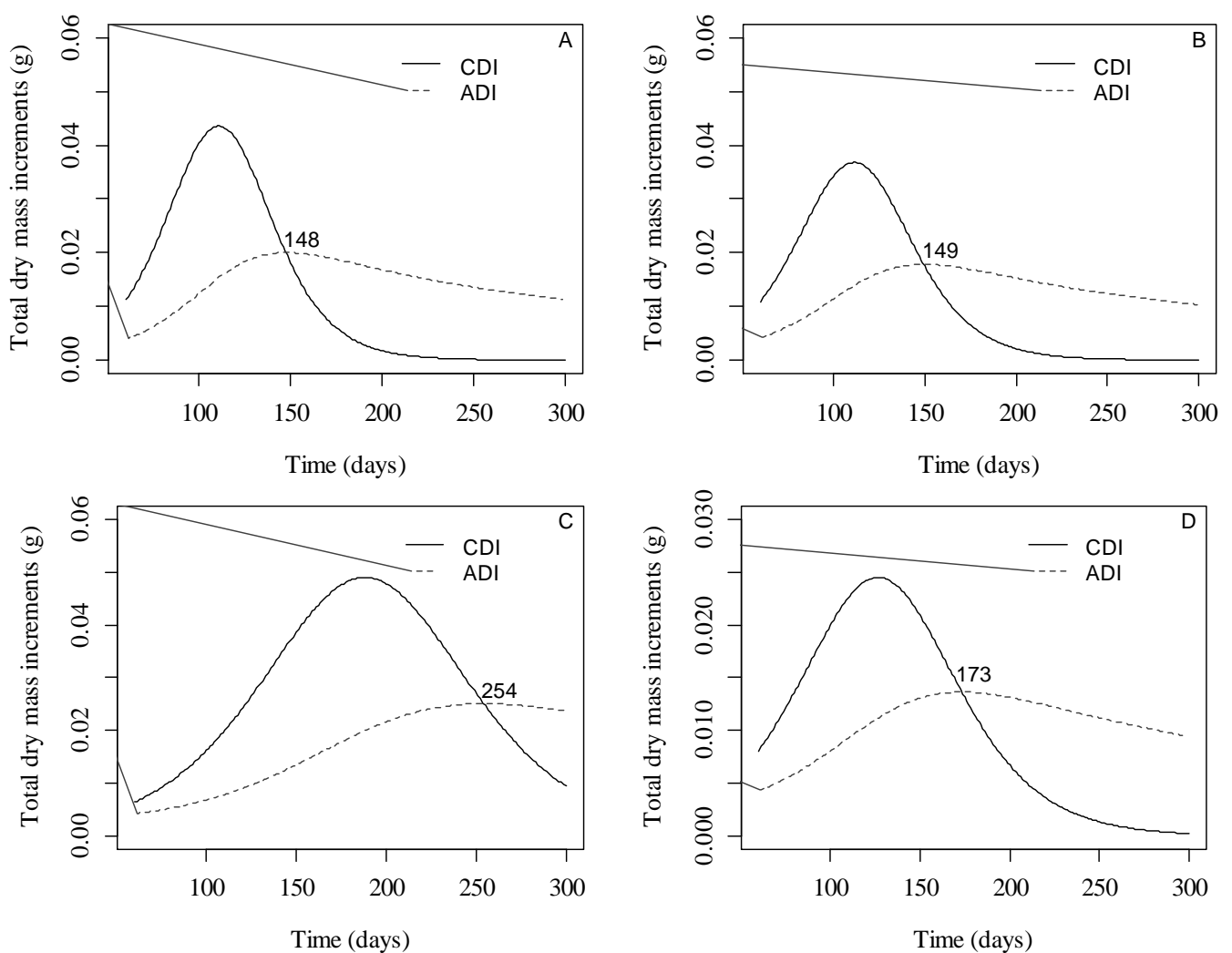

Figure 4: Current daily increments (CDI) and average daily increments (ADI) for total dry mass according to the age of the American Cordia seedlings, according to the treatments: $\mathrm{T} 1=$ seedlings developing in large tubes (170 $\left.\mathrm{cm}^{3}\right)$ in high density $\left(237\right.$ tubes $\left.\mathrm{m}^{-2}\right)(\mathrm{A}) ; \mathrm{T} 2=$ in large tubes and medium density $\left(118\right.$ tubes $\left.\mathrm{m}^{-2}\right)(\mathrm{B}) ; \mathrm{T} 3=$ medium tube $\left(90 \mathrm{~cm}^{3}\right)$ and high density $\left(434\right.$ tubes $\left.\mathrm{m}^{-2}\right)(\mathrm{C})$ and $\mathrm{T} 4=$ medium tube + medium density $\left(217\right.$ tubes $\left.\mathrm{m}^{-2}\right)(\mathrm{D})$. 
The size of the tube and the density of the seedlings in the tray influence the growth of Cordia americana seedlings. In the present study, it was found that 148 (T1), 149 (T2), 254 (T3), 173 (T4) days were sufficient for the expedition of seedlings with a suitable quality standard in relation to the dry mass of plants.

\section{Conclusion}

The large tube and the density of $100 \%$ provided the shortest seedling time in the nursery. The intercept between the curves of daily increment and average daily increment, using the morphological parameters, is useful in the decision making to determine the period of permanence of the Cordia americana seedlings with a view to the evaluation of the quality standard of the seedlings.

\section{Referencias}

Abreu AHM, Leles PSS, Melo LA, Ferreira DHAA, Monteiro FAZ (2015) Produção de mudas e crescimento inicial em campo de Enterolobium contortisiliquum produzidas em diferentes recipientes. Floresta, 45(1): 141-150.

<http://revistas.ufpr.br/floresta/article/viewFile/289 31/24819>

Alvares CA, Stape JL, Sentelhas PC, Gonçalves JLM, Sparovek G (2013) Köppen's climate classification map for Brazil. Meteorologische Zeitschrift, 22(6): 711-728.

<https://doi.org/10.1127/0941-2948/2013/0507>

Antoniazzi AP, Binotto B, Neumann GM, Sausen TL, Budke JC (2013) Eficiência de recipientes no desenvolvimento de mudas de Cedrela fissilis Vell. (Meliaceae). Revista brasileira de Biociências, 11(3): 313-317.

<http://www.ufrgs.br/seerbio/ojs/index.php/rbb/arti cle/view/2390>

Caldeira MVW, Delarmelina WM, Lübe, SG, Gomes DR, Gonçalves EO, Alves AF (2012) Biossólido na composição de substrato para a produção de mudas de Tectona grandis. Floresta, 42(1): 77-84.

<http://dx.doi.org/10.5380/rf.v42i1.26302>

Caldeira MVW, Marcolin M, Moraes E, Schaadt SS (2007) Influência do resíduo da indústria do algodão na formulação de substrato para produção de mudas de Schinus terebinthifolius Raddi, Archontophoenix alexandrae Wendl. et Drude e Archontophoenix cunninghamiana Wendl. et Drude. Ambiência, 3: 18.

Campos J C C, Leite H G (2006) Mensuração florestal: perguntas e respostas. 2. ed. Viçosa: UFV. 407 p.

3

Adv. For. Sci, Cuiabá, v. 7, n. 1, p. 897-904, 2020
Carneiro JGA (1995) Produção e controle de qualidade de mudas florestais. Curitiba: Campos/UENF. UFPR/FUPEF, 451 p.

Cavalcante ALG, Oliveira FA, Pereira KTO, Dantas RP, Oliveira MKT, Cunha RC, Souza MWL (2016) Desenvolvimento de mudas de mulungu fertirrigadas com diferentes soluções nutritivas. Floresta, 46(1): 47-55.

<http://dx.doi.org/10.5380/rf.v46i1.34888>

Constantino V, Higa AR, Silva LD, Rosa JMC, Viana JJ (2010) Efeitos de métodos de produção de mudas e equipes de plantadores no crescimento de Pinus taeda Linnaeus. Scientia Forestalis, 38(87): 355-366.

<http://www.ipef.br/publicacoes/scientia/nr87/cap0 3.pdf>

Dickson A, Leaf AL, Hosner JF (1960) Quality appraisal of white spruce and white pine seedling stock in nurseries. Forestry Chronicle, 36: 10-13. $<$ http://pubs.cififc.org/doi/pdfplus/10.5558/tfc3601 $0-1>$

Eloy E, Caron BO, Schmidt D, Behling A, Schwers L, Elli EF (2013) Avaliação da qualidade de mudas de Eucalyptus grandis utilizando parâmetros morfológicos. Floresta, 43(3): 373-384.

<http://dx.doi.org/10.5380/rf.v43i3.26809>

Fonseca EP, Valeri SV, Miglioranza E, Fonseca NAN, Couto L (2002) Padrão de qualidade de mudas de Trema micrantha (L.) Blume. produzidas sob diferentes períodos de sombreamento. Revista Árvore, 26(4): 515-523.

<http://dx.doi.org/10.1590/S010067622002000400 015>

Gomes DR, Caldeira MVW, Delarmelina WM, Gonçalves EO, Trazzi PA (2013) Lodo de esgoto como substrato para a produção de mudas de Tectona grandis L. Cerne, 19(1): 123-131. <http://dx.doi.org/10.1590/S010477602013000100 015>

Gomes JM, Couto L, Leite HG, Xavier A, Garcia SLR (2002) Parâmetros morfológicos na avaliação da qualidade de mudas de Eucalyptus grandis. Revista Árvore, 26(6): 655-664. <http://dx.doi.org/10.1590/S010067622002000600 002>

Hermann R K (1964) Importance of top-root ratios for survival of Douglas-fir seedlings. Tree Planters Notes, 64: 7-11.

Leite H G, Oliveira F H T (2002) Statistical method to test the identity of analytical methods. 
Communications in Soil Science Plant Analysis 6: 22.

Lisboa AC, Santos PS, Neto SNO, Castro DN, Abreu AHM (2012) Efeito do volume de tubetes na produção de mudas de Calophyllum brasiliense e Toona ciliata. Revista Árvore, 36(4): 603-609. < http://dx.doi.org/10.1590/S01006762201200040000 3>

Mafia RG, Alfenas AC, Siqueira L, Leite HG, Cavallazzi JRP (2005) Critério técnico para determinação da idade ótima de mudas de eucalipto para plantio. Revista Árvore, 29(6): 947-953. < http://dx.doi.org/10.1590/S01006762200500060001 4>

Oliveira LSB, Andrade LA, Alves AS, Gonçalves GS (2014) Substrato e volume de recipiente na produção de mudas de jatobá (Hymenaea courbaril L.). Nativa, 2(2): 103-107.

<http://dx.doi.org/10.14583/2318-670.v02n02a07>

Reis ER, Lúcio ADC, Fortes FO, Lopes SJ, Silveira SD (2008) Período de permanência de mudas de Eucalyptus grandis em viveiro baseado em parâmetros morfológicos. Revista Árvore, 32(5): 809-814.

<http://dx.doi.org/10.1590/S010067622008000500 004>

Rossato MS (2014) Os climas do Rio Grande do Sul: Tendências e tipologias. In: Mendonça, F. (ed). Os climas do Sul: Em tempos de mudanças climáticas globais. Jundiaí: Paco Editorial, p.217-271.

Santos CB (2000) Efeito do volume de tubetes e tipos de substratos na qualidade de mudas de Cryptomeria japonica. Ciência Florestal, 10(2): 115.

SAS LEARNING EDITION. Getting started with the SAS learning edition. Cary, 2003. 200 p.

Teixeira PC, Rodrigues HS, Lima WAA, Rocha RNC, Cunha RNV, Lopes R (2009) Influência da disposição dos tubetes e da aplicação de fertilizantes de liberação lenta, durante o pré-viveiro, no crescimento de mudas de dendezeiro (Elaeis guineensis Jacq.). Ciência Florestal, 19(2): 157-168. <http://dx.doi.org/10.5902/19805098407>

Vallone HS, Guimarães RJ, Mendes ANG, Souza CAS, Cunha RL, Dias FP (2010) Diferentes recipientes e substratos na produção de mudas de cafeeiros. Ciência e Agrotecnologia, 34(1): 55-60. < http://dx.doi.org/10.1590/S14137054201000010000 $6>$ 